\title{
IL2RG wt Allele
}

National Cancer Institute

\section{Source}

National Cancer Institute. IL2RG wt Allele. NCI Thesaurus. Code C51364.

Human IL2RG wild-type allele is located in the vicinity of Xq13.1 and is approximately $4 \mathrm{~kb}$ in length. This allele, which encodes cytokine receptor common gamma protein, plays a role in interleukin signal transduction and regulation. Mutations in the gene cause X-linked severe combined immunodeficiency or (XSCID). 